\title{
Life Cycle Inventory of Institutional Medium-scaled Co-composting of Food Waste and Yard Waste in Tropical Country
}

(Inventori Kitaran Hidup di Institusi pada Skala Sederhana Pengkomposan bersama Sisa Makanan dan Sisa Lapangan di Negara Tropika)

\author{
CHEE GuAn NG* \& SuMIANI YUSOFF
}

\begin{abstract}
The main objective of the present study was to provide a comprehensive LCI of medium scale composting of food waste and yard waste at institutional level, based on substance flow analysis (SFA). A secondary objective was to present the composition and assess the quality of the final compost product from composting of typical Asian organic waste (food waste and yard waste). The experiments were designed to represent a batch situation in an institutional medium size composting scenario with input material of food waste mixed with grass clippings and dried leaves. Two composting runs were carried out with the intention to showcase the heterogeneity of organic waste and study the effect of windrow size on the performance of the process. The input and output material were sampled and characterized in order to quantify the substance balance of the process. SFA was performed by means of the mass balance model STAN 2.5 to compute unknown parameters (gaseous emissions). SFAs have been performed for $\mathrm{C}, \mathrm{N}, \mathrm{K}, \mathrm{P}, \mathrm{Cd}, \mathrm{Cr}, \mathrm{Cu}, \mathrm{Ni}$ and $\mathrm{Pb}$. The composting windrows were fed with 212.4 and $393 \mathrm{~kg}$, respectively. VS content reduction is greater in composting pile with larger size (Run 2). The loss of C during composting was recorded in the range of 0.146-0.166 $\mathrm{kg} / \mathrm{kg} \mathrm{ww}$. The C losses via leachate were insignificant (0.02\% of the total input $C$ ). The total $N$ loss during the process was 0.005-0.012 $\mathrm{kg} / \mathrm{kg} \mathrm{ww}$. The leachate generation was measured as $0.012-0.013 \mathrm{~kg} / \mathrm{kg} \mathrm{ww}$. The flows of selected heavy metals were assessed. Heavy metals were of minor significance due to low concentrations in the inputs (food waste and yard waste). Heavy metals were found to be released to the atmosphere. However, majority of heavy metals remain in the finished compost. The $C / N$ reduction during the process was in the range of 10-23\%. In general, the compost composition was considered to be within the ranges previously reported in literature and thus ready for application in gardening. The LCI presented in the present study can be used as a starting point for making environmental assessments of medium-scale co-composting of food waste and yard waste in tropical environment. No major environmental problems were identified from the process, except for the emissions of GHGS.
\end{abstract}

Keywords: Composting; direct emissions; food waste; life cycle inventory; substance flow analysis; yard waste

\section{ABSTRAK}

Objektif utama kajian ini adalah untuk memberi LCI yang komprehensif pada skala sederhana pengkomposan sisa makanan dan sisa lapangan pada peringkat institusi, berdasarkan pada analisis aliran bahan (SFA). Objektif kedua adalah untuk membentangkan komposisi dan menilai kualiti produk akhir daripada pengkomposan sisa organik tipikal Asia (sisa makanan dan sisa lapangan). Eksperimen direka untuk mewakili situasi kumpulan di institusi dengan senario pengkomposan saiz sederhana dengan input bahan sisa makanan yang bercampur dengan keratan rumput dan daun kering. Dua pusingan pengkomposan telah dijalankan dengan tujuan untuk menunjukkan keheterogenan sisa organik dan mengkaji kesan saiz timbunan ke atas prestasi proses. Bahan input dan output yang telah disampel dan dicirikan untuk menentukan baki bahan proses. SFA telah dijalankan melalui imbangan jisim model STAN 2.5 untuk mengira parameter yang tidak diketahui (pelepasan gas). SFAs telah dijalankan bagi $\mathrm{C}, \mathrm{N}, \mathrm{K}, \mathrm{P}, \mathrm{Cd}, \mathrm{Cr}, \mathrm{Cu}, \mathrm{Ni}$ dan $\mathrm{Pb}$. Timbunan pengkomposan masing-masing diberikan 212.4 dan $393 \mathrm{~kg}$. Pengurangan kandungan VS adalah lebih besar dalam timbunan pengkomposan dengan saiz yang lebih besar (Pusingan 2). Kehilangan C semasa pengkomposan direkod dalam julat antara 0.146 dan $0.166 \mathrm{~kg} / \mathrm{kg} \mathrm{ww}$. Kehilangan C melalui larut lesap adalah tidak ketara (0.02\% daripada jumlah input C). Jumlah kehilangan $N$ semasa proses adalah 0.005-0.012 kg/kg ww. Penghasilan larut lesap adalah sebanyak 0.012-0.013 kg/kg ww. Aliran logam berat terpilih turut dinilai. Logam berat tidak ketara disebabkan kepekatan yang rendah dalam input (sisa makanan dan sisa lapangan). Logam berat dilepaskan ke atmosfera. Walau bagaimanapun, kebanyakan logam berat kekal dalam hasil pengkomposan. Pengurangan C/N semasa proses adalah dalam lingkungan 10-23\%. Secara umum, komposisi pengkomposan dianggap berada dalam julat seperti yang dilaporkan dalam kajian sebelum ini dan sekali gus bersedia untuk digunakan dalam berkebun. LCI yang dikemukakan dalam kajian ini boleh digunakan sebagai titik permulaan untuk menjadikan penilaian alam sekitar pada skala sederhana pengkomposan bersama sisa makanan dan sisa lapangan dalam persekitaran tropika. Tiada masalah alam sekitar yang utama dikenal pasti daripada proses tersebut, kecuali pelepasan GHG. 


\section{INTRODUCTION}

Composting has been considered as a potential major diversion route for municipal solid waste (MSW) particularly organic waste (food waste and yard waste) (Andersen et al. 2012). The potential of composting is to provide a flexible, low cost approach to waste management and facilitate sustainable recycling scheme for a region. However, it requires active participation of a significant number of waste generators in source-separating the desired organic waste for composting effort in order to impact waste diversion rates. This could be obtained by promoting medium scale centralized composting covering a reasonable number of waste generators, for instance on institutional level (higher education institutions).

The most obvious environmental advantage of doing medium scale institutionalized composting compared to home composting is the economics of scale and better control of the composting feedstock and process. As compared with larger scale composting, huge collection and transportation can be avoided as medium scale composting normally serves small community where the desired separated organic waste can be easily delivered. Another advantage relevant for medium scaled centralized composting is the production of compost, which could potentially be used in the yard as soil conditioner and hence replace the use of peat and mineral fertilizer (Rea et al. 2009; Russo et al. 2011). This could however, create negative impacts to the environment, if the produced contain high heavy metal content (Andersen et al. 2011).

In contrast, the main disadvantage of composting is the emission of greenhouse gases (GHGs) and leachate contamination from the composting process contributing to global warming and pollution (Andersen et al. 2011) despite the fact that replacement of peat and mineral fertilizer could bring upon credit to environmental impact (savings). A study in the United States showed that $90 \%$ of the overall carbon dioxide emissions in composting facilities were due to the biological decomposition of the organic substrate, while the rest was due to fossil fuel combustion (Komilis \& Ham 2004). However, as compared to the overall municipal solid waste management system in China, kitchen waste composting makes a considerable contribution to total GHG emissions reduction (Zhao et al. 2009).

The composting process is taking different ways and with very different operational schemes, subject to availability of suitable waste and separation efficiency. The large variation in composting operation schemes across the world, results in the lack of scientific studies in this field. Some inventory data for composting were found in literature. However most of the literature found focused in small-scaled home composting unit. A full life cycle inventory (LCI) had been performed on home composting by Colón et al. (2010), but the GHG emission and leachate generation was not well assessed. Another study focusing only in GHG emissions from multi-family home compositing had been carried out (Amlinger et al.
2008). Besides, a mass balance study employed weekly additions of waste (2.6 to $3.5 \mathrm{~kg}$ per week) into the composting process which had been carried out targeting on single-family composting (Andersen et al. 2011). All literature found focused on composting at rather small scale, fed with yard waste only, with slower degradation rate. Another study on the combination of the thermocomposting and vermicomposting of kitchen waste carried out. The test however, focused on the mass reduction, moisture management and pathogen reduction only (Nair et al.2006). The study showed that kitchen waste is best to be vermin-composted with cow dung, as shown by higher percentage of nutrient elements in the vermin-compost produced and the multiplication of earthworms at the end of vermin-composting process (Adi \& Noor 2009).

On a larger scale, studies on environmental evaluation caused by changes of food waste management systems in Korea and Singapore were carried respectively (Khoo et al. 2010; Kim \& Kim 2010; Lee et al. 2007). According to the studies, the impacts on acidification, eutrophication and fresh water aquatic eco-toxicity were increased due to the high energy consumption and generated residue in recycling systems. Both studies however did not reveal the methods to quantify the emissions from the composting process. It is interesting to note that another study was carried out to quantify the airborne and waterborne emissions from in-vessel composting facility. The air emissions and water effluent were however taken after the treatment process (Cabaraban et al. 2008), which did not represent the generic environmental burdens caused by open composting of organic feedstock. Although composting was deemed the best food waste management option, it can perform worst environmentally due to high GHG emissions consequent to anaerobic methanogenesis (Lundie \& Peters 2005).

When exploring the relationship between environmental performance and organic waste management, the volume and physical composition of the waste matter must be taken into account. Due to differences in local environments and lifestyle, the quantity and composition of food waste often vary. This leads to differences in environmental burdens generated, particularly the GHG emissions, highlighting the need for local research (Chen \& Lin 2008). Moreover, there has until now been a lack of full LCIs for medium scale co-composting of food waste and yard waste at hot and moist weather throughout the year. Hence, this study could be deemed as the first attempt in quantifying the environmental burdens of co-composting of food waste and yard waste in tropical climate.

The main objective of the present study was to provide a comprehensive LCI of medium scale co-composting of food waste and yard waste at institutional level, based on substance flow analysis (SFA). A secondary objective was to present the composition and assess the quality of the final compost product from composting of typical Asian organic waste (food waste and yard waste). The experimental set-up was prepared with the intention of representing the 
real management of organic waste composting process in University of Malaya, Kuala Lumpur.

\section{METHODS}

LCI of food waste and yard waste composting process was constructed via a series of methods. The LCI was supported by the comprehensive field work studies which include energy and water consumption during the composting process as well as the process emissions in terms of gaseous and liquid. The data on energy and water consumption was collected during the composting process while the process emissions were estimated using Substance Flow Analysis (SFA) method. Experiment for composting runs was conducted in order to assess the selected substances content of the feedstock, leachate and finished compost. The gaseous and liquid emissions were then estimated. The summary of the methodology was illustrated in Figure 1.

\section{EXPERIMENTAL SET-UP}

The experimental set-up represents a typical size of compost pile in the composting site of University of Malaya. In order to avoid external disturbance such as rain and pets, the compost pile is covered with a cylindrical chamber made from waterproof material (PVC) $3 \mathrm{~m}$ in diameter and $2.2 \mathrm{~m}$ high with a volume of $13 \mathrm{~m}^{3}$ and installed on a water-proof concrete floor. Fresh air was introduced through a space between the floor and the lower edge of the chamber and an inverter-controlled blower sucked exhaust gas from the middle of the ceiling. The ventilation rate was fixed to 130 $\mathrm{m}^{3} / \mathrm{h}$ (Fukumoto et al. 2003). Two composting runs were carried out with the intention to showcase the heterogeneity of organic waste (food waste and yard waste) and study the effect of windrow size on the performance of the process.

\section{EXPERIMENTAL OUTLINE AND FEEDSTOCK}

The experiments were designed to represent a batch situation in an institutional medium size composting scenario. The input material consisted of food waste mixed with grass clippings and dried leaves. Fresh food waste was collected from selected cafeterias in university campus and mixed with grass clippings and dried leaves to adjust the moisture content to approximately $65 \%$. Immediately after the mixing, the mixture was piled up conically inside the chamber. Introduction of small amount of semi-matured compost into the composting pile helped initiate the decomposition of the organic matter in the pile. Each composting run was carried out for the duration of 60 days. Initial height of the pile and diameter of the base were about 0.7 and $1.4 \mathrm{~m}$. The material was completely turned once in each run. At the end of the composting period, the mixture was weighed.

\section{COLLECTION OF DATA}

The emissions were primarily in gaseous form and leachate. Water, electricity and fuels were used indirectly with the composting process (cleaning, shredding and grinding). The input and output material were sampled and characterized in order to quantify the substance balance of the process. LCI covers all consumptions and emissions of environmental importance (ISO 1998). In the present inventory study, only the direct emissions from the composting process have been included. The facility set-up, production of composting tools and transportation associated to this were not addressed. The provided LCI form the basis for doing environmental assessments of composting at institutional level in future.

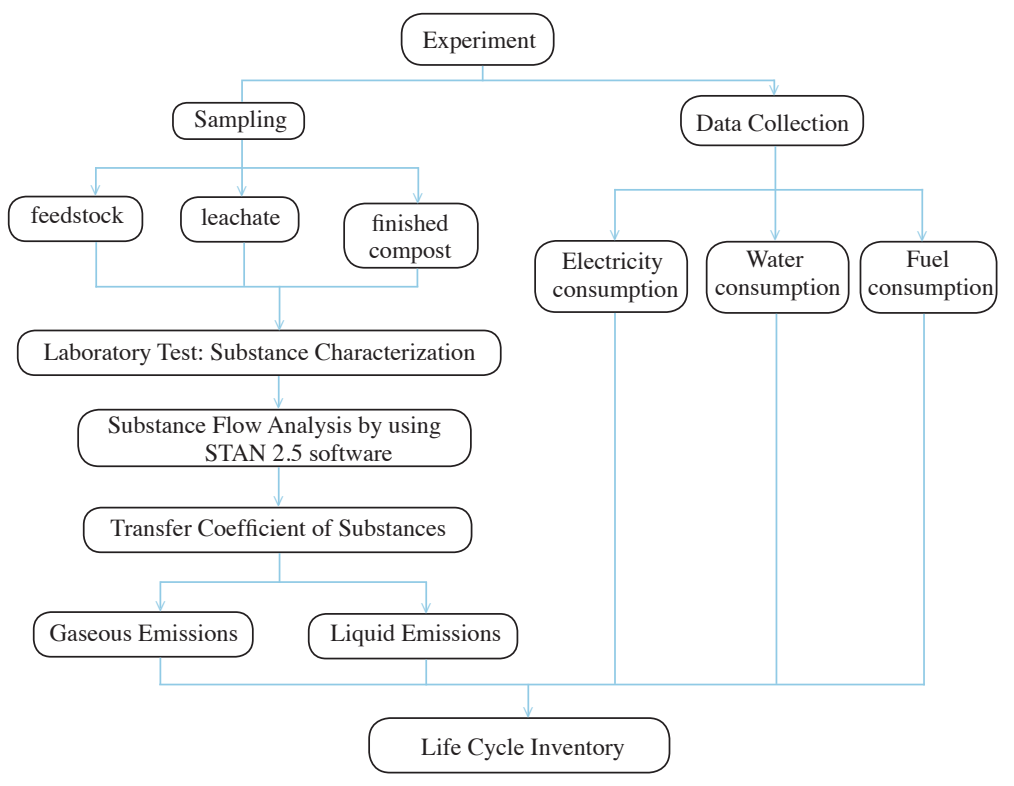

FIGURE 1. Summary of Methods 


\section{SAMPLING OF SOLIDS}

Sampling of the feedstock was performed before and after every run. Two samples (duplicates), each $1 \mathrm{~kg}$ (mass) of the input materials, were taken from composting pile (run). Grab sampling was adopted to be as representatively as possible. The output of the composting after 60 days was weighted and spread on a piece of clean plastic sheet. Sample was obtained from the compost by using quartering method. Finished compost was divided randomly into four sub-groups. Two random apposite sub-groups were mixed up together and further divided into four equal sub-groups. Two random apposite of the sub-groups were mixed again to form four sub-groups. The procedures were repeated until approximately $1 \mathrm{~kg}$ of the samples was obtained. The collected samples were oven-dried for keeping the samples solid and brittle before ground into smaller particle by using stone grinder and mass reduction of the sample was performed by quartering method (as described above) to obtain $20 \mathrm{~g}$ laboratory samples. The samples were then divided into duplicates ( $10 \mathrm{~g}$ each) for analysis. The stone grinder was cleaned thoroughly between samples to avoid cross contamination. For determination of the flow of material and substances, weighted average of the parameters from the two samples $(10 \mathrm{~g})$ was used. Total solids (TS) content of the input and output material was measured by drying the samples at $105^{\circ} \mathrm{C}$ for about $24 \mathrm{~h}$ (or until constant weight). Volatile Solids (Vs) content was measured a mass loss after heating the sample at $550^{\circ} \mathrm{C}$ for $1 \mathrm{~h}$. Two replicates per sample were sent for elemental analysis with CHNS analyzer-2400 Series II (for C, N) and ICP-OES (for $\mathrm{P}, \mathrm{K}, \mathrm{Cd}, \mathrm{Cr}, \mathrm{Cu}, \mathrm{Ni}$ and $\mathrm{Pb}$ ) (PerkinElmer 2012). The analyzed data were used as input parameters in the SFA modelling.

\section{LEACHATE SAMPLING}

Leachate from the composting pile was considered a contributor to environmental impacts. The experiments were prepared with leachate collection to estimate the quantity and quality of the leachate. A plastic sheep was inserted on the inclined platform where the composting pile was placed to collect the leachate. The leachate was collected in a clean plastic container and weighted. Samples of collected leachate were sent for chemical composition analyses.

\section{SUBSTANCE FLOW ANALYSIS}

SFA was performed by means of the mass balance model STAN 2.5, which perform SFA according to the Austrian standard ONorm 2096 (Cencic \& Rechberger 2008). SFAs have been performed for $\mathrm{C}, \mathrm{N}, \mathrm{K}, \mathrm{P}, \mathrm{Cd}, \mathrm{Cr}, \mathrm{Cu}, \mathrm{Ni}$ and $\mathrm{Pb}$. The uncertainty of concentrations in the flows was inserted based on the standard deviation of the duplicate samples. Simulations were performed, to compute the gaseous emissions (unknown parameters) based on the known substances content in feedstock, leachate and finished compost. The gaseous emissions to the atmosphere during the composting process were estimated by STAN 2.5 for all selected substances. $\mathrm{CO}_{2}$ emissions were assumed as $95 \%$, $\mathrm{CH}_{4}$ as $4 \%$ and $\mathrm{CO}$ as $1 \%$ of the lost $\mathrm{C}$. $\mathrm{NH}_{3}$ emissions were made up $0.004 \%$ of the total losses of $\mathrm{N}$ where $\mathrm{N}_{2} \mathrm{O}$ contributes $6.3 \%$ of the total loss of $\mathrm{N}$.

\section{RESULTS}

\section{FEEDSTOCK QUANTITIES AND COMPOSITION}

The amount of waste added to each composting run was 210-393 kg (Figure 2). The composition of the input material is given in Table 1. The moisture content was in the range of 72-74\%ww (food waste) and 40-46\% ww (yard waste) whereas, the organic content (VS) was $67-98 \%$ TS (food waste) and $72-80 \%$ Ts (yard waste). The $\mathrm{C}$ content was $64-70 \%$ Ts (food waste) and 41-46\%Ts (yard waste). The $\mathrm{N}$ content in yard waste $(2-3 \%)$ is lower than that of food waste (5-7\%). The mixture of food waste and yard waste in Run 1 and Run 2 gave C/N ratios of 14-16. The concentrations of heavy metals and nutrients of the input materials were in the range of values given in the literature for organic household waste (Riber et al. 2007).

\section{CHEMICAL COMPOSITION AND QUALITY OF COMPOST}

The composition of the compost from both composting runs is presented in Table 1 . The key parameters were moisture content, ash content, $\mathrm{C}$ content and $\mathrm{N}$ content. These parameters are all within the reported range for compost materials except moisture content, which exhibits lower value. The heavy metal contents in composts are in agreement with the range reported by literature (Andersen et al. 2011; Colón et al. 2010; Jasim \& Smith 2003; Martínez-Blanco et al. 2010; Papadopoulos et al. 2009). The quality of the final compost was assessed visually and from some key parameters. In all cases, food waste is no longer visible in the compost. Finished compost had dark brown colour and urine smell, indicating leaching of ammonia. A common parameter that indicates that composting process was taking place is the $\mathrm{C} / \mathrm{N}$ ratio. The decrease of $\mathrm{C} / \mathrm{N}$ ratio (10-23\%) and Vs (17-33\%) were recorded from both composting runs.

\section{LEACHATE VOLUME AND QUALITY}

The total leachate generations over 60 days were $2.5 \mathrm{~kg}$ (run 1) and $5.0 \mathrm{~kg}$ (run 2). The leachate generation was divided by respective input waste to get a generation of 0.012 and $0.013 \mathrm{~kg} / \mathrm{kg}$ ww for both runs, respectively (meaning a loss of 1.2-1.3\% of the wet weight of the wet material through leachate). The composition of leachate for both runs is presented in Table 2 .

\section{SUBSTANCE BALANCE}

The mass balance of two experiment runs is shown in Figure 2. During the composting period, 58-73\% of the material (including water) was lost to the atmosphere. 


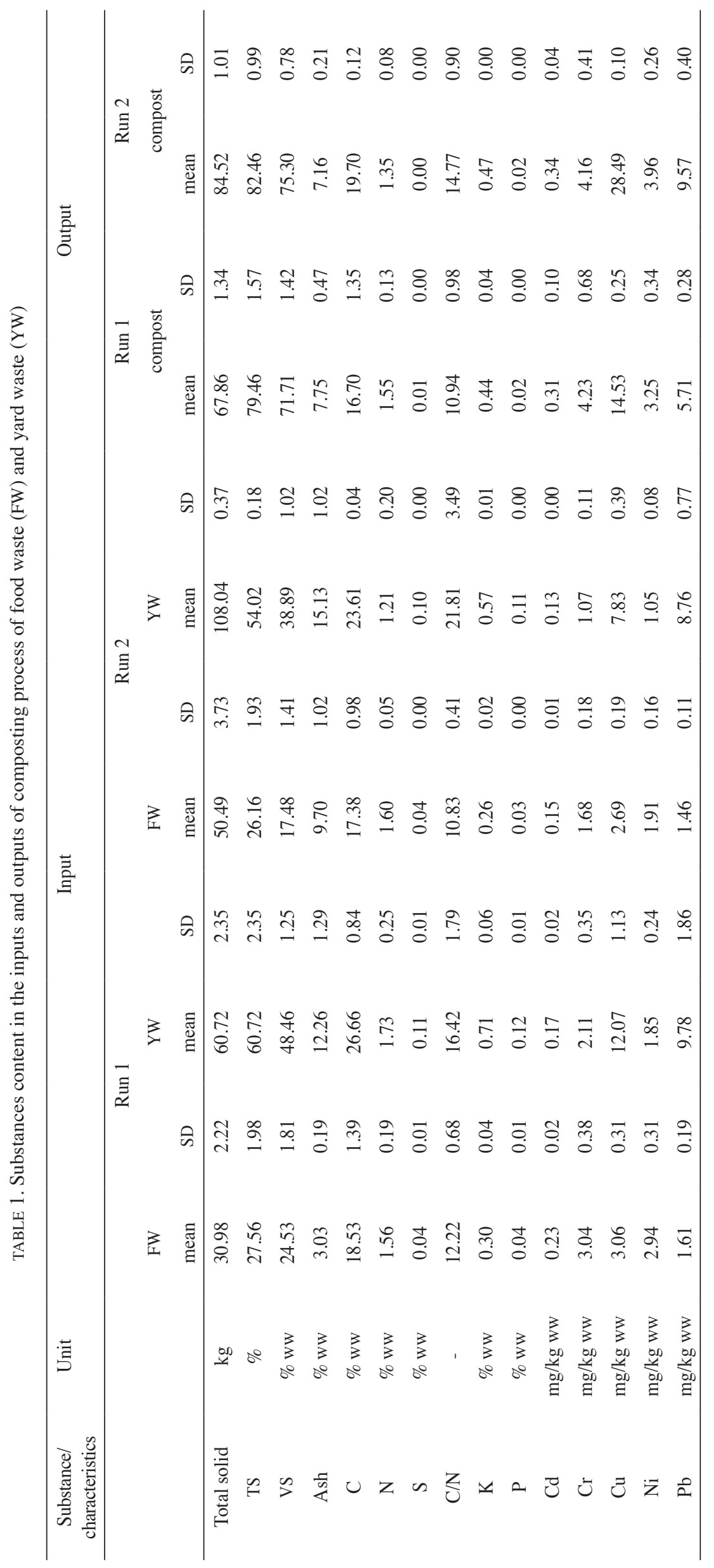


TABLE 2. Composition of leachate from co-composting of food waste and yard waste

\begin{tabular}{llll}
\hline Parameter & Unit & \multicolumn{1}{c}{ Run 1} & \multicolumn{1}{c}{ Run 2} \\
\hline $\mathrm{pH}$ & - & $5.26 \pm 0.10$ & $6.20 \pm 0.10$ \\
$\mathrm{TOC}$ & $\mathrm{mg} / \mathrm{L}$ & $3250 \pm 149.14$ & $3122 \pm 178.87$ \\
$\mathrm{BOD}$ & $\mathrm{mg} / \mathrm{L}$ & $6576 \pm 294.40$ & $8400 \pm 272.88$ \\
$\mathrm{COD}$ & $\mathrm{mg} / \mathrm{L}$ & $14143 \pm 555.99$ & $17593 \pm 487.92$ \\
$\mathrm{P}$ & $\mathrm{mg} / \mathrm{L}$ & $79.2 \pm 5.20$ & $54 \pm 3.54$ \\
$\mathrm{~K}$ & $\mathrm{mg} / \mathrm{L}$ & $5640 \pm 900.92$ & $7031 \pm 1051.77$ \\
$\mathrm{TKN}$ & $\mathrm{mg} / \mathrm{L}$ & $55.4 \pm 8.35$ & $84.9 \pm 4.17$ \\
$\mathrm{Cd}$ & $\mathrm{mg} / \mathrm{L}$ & $0.00 \pm 0.00$ & $0.00 \pm 0.00$ \\
$\mathrm{Cr}$ & $\mathrm{mg} / \mathrm{L}$ & $0.02 \pm 0.00$ & $0.02 \pm 0.00$ \\
$\mathrm{Cu}$ & $\mathrm{mg} / \mathrm{L}$ & $0.02 \pm 0.00$ & $0.02 \pm 0.00$ \\
$\mathrm{Ni}$ & $\mathrm{mg} / \mathrm{L}$ & $0.07 \pm 0.02$ & $0.08 \pm 0.00$ \\
$\mathrm{~Pb}$ & $\mathrm{mg} / \mathrm{L}$ & $0.10 \pm 0.02$ & $0.14 \pm 0.01$ \\
\hline
\end{tabular}
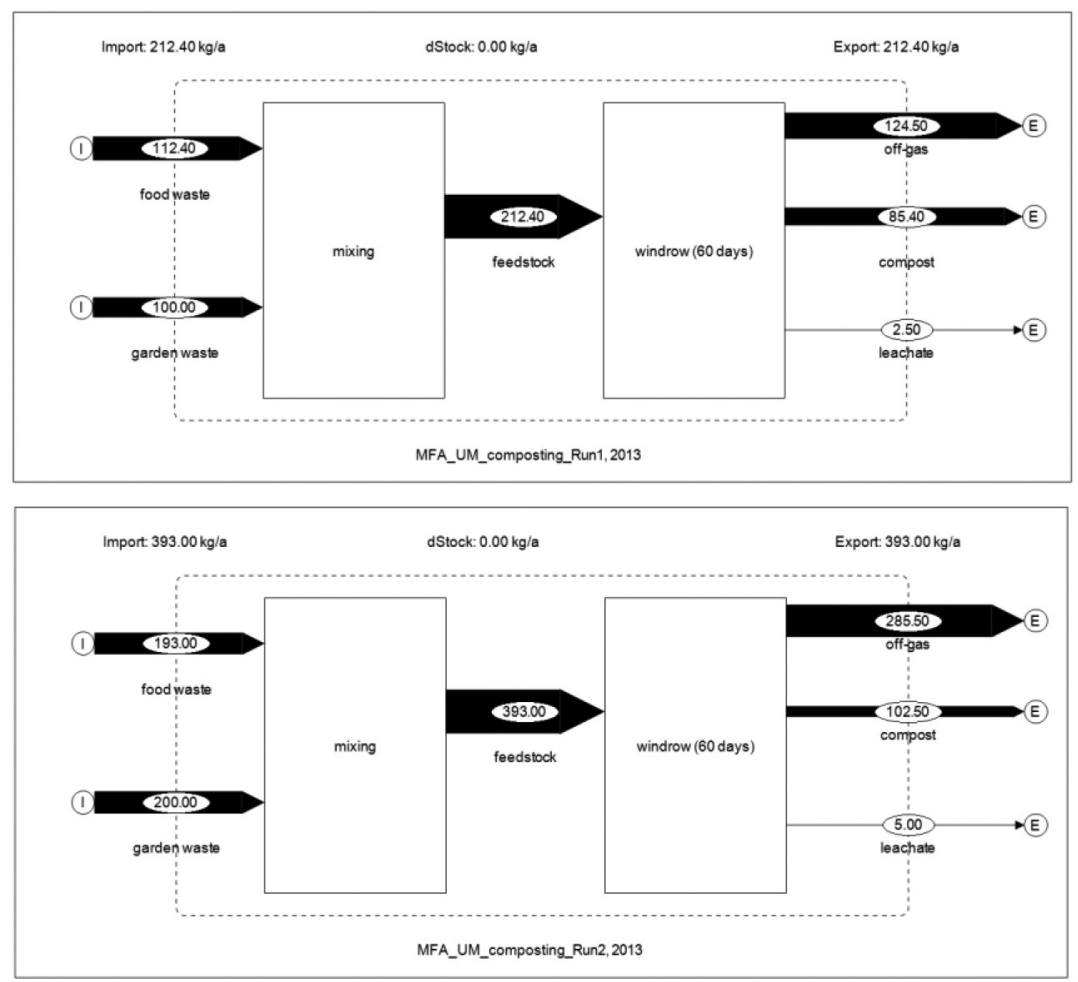

FIGURE 2. Mass flow of co-composting of food waste and yard waste in $\mathrm{kg}$

The C loss was $67-73 \%$ and $74-76 \%$ for Runs 1 and 2, respectively. The $\mathrm{N}$ loss to atmosphere recorded higher for Run 2 (72-78\%) than Run 1 (44-59\%). Portions of heavy metals and the nutrients $(\mathrm{P}$ and $\mathrm{K})$ are all found to be emitted to the air. The concentrations of nutrients and heavy metals in the leachate were found to be very low. The contents of substance remains in the compost are shown in Table 1.

\section{LIFE CYCLE INVENTORIES}

The full LCI is presented in Table 4. As mentioned previously, the main contributors to the LCI are gaseous emissions and loss of leachate. In addition to the reported emissions, other gases (such as volatile organic compounds), could be produced and emitted during the composting process, but there were thought to be of minor importance.

\section{DISCUSSION}

\section{QUALITY OF COMPOST}

The composition of the compost produced from both runs was in agreement with the compositions reported previously in the literature as shown in Table 1. The moisture content seems to be very low (17-20\%). This may due to the tropical climate where the ambient temperature is averagely high throughout the year. 
However, moisture content of below $50 \%$ is recommended to keep the handling, transportation and application feasible. The vs of the compost is higher as compared to the literature (Colón et al. 2010), which indicates that considerable content of organic matter in the compost output. A longer period of degradation time is needed to reduce the VS content of the compost. However, if the VS content (fraction) is to be multiplied to the total weight of the compost, it shows a reduction of Vs of $17-21 \%$ (Run 1) and $28-33 \%$ (Run 2). vs content reduction is greater in composting pile with larger size (Run 2) with input materials of $193 \mathrm{~kg}$ food waste and $200 \mathrm{~kg}$ yard waste. This may due to the larger heat retention potential within the pile in order to provide an optimum environment to the aerobic microorganisms. The compost material had a brown colour where some branches are apparent, hence, longer degradation time is required to further degrade the slow-degrading yard waste. The decrease in $\mathrm{C} / \mathrm{N}$ ratio also indicated that composting took place in both composting runs.

\section{AND N BALANCE}

The loss of $\mathrm{C}$ via leachate was in all cases insignificant as shown in Table 3. This means that $24-33 \%$ of $\mathrm{C}$ in the input material was left in the compost. The $\mathrm{C}$ balance was in all cases quite good and for all composting units; the loss of $\mathrm{C}$ to air was higher in Run 2. Figure 3 shows that $\mathrm{C}$ loss to air is greater from co-composting of food waste and yard waste in larger windrow size. This is in

TABLE 3. Transfer coefficients of selected substances to off-gas, compost and leachate for co-composting of food waste and yard waste

\begin{tabular}{|c|c|c|c|c|c|c|c|c|c|c|c|c|}
\hline \multirow[t]{3}{*}{ Substance } & \multicolumn{6}{|c|}{ Run 1} & \multicolumn{6}{|c|}{ Run 2} \\
\hline & \multicolumn{2}{|c|}{ TC off gas } & \multicolumn{2}{|c|}{ TC compost } & \multicolumn{2}{|c|}{ TC leachate } & \multicolumn{2}{|c|}{ TC off gas } & \multicolumn{2}{|c|}{ TC compost } & \multicolumn{2}{|c|}{ TC leachate } \\
\hline & $\min$ & $\max$ & $\min$ & $\max$ & $\min$ & $\max$ & $\min$ & $\max$ & $\min$ & $\max$ & $\min$ & $\max$ \\
\hline Carbon & 0.67 & 0.73 & 0.27 & 0.33 & 0.00 & 0.00 & 0.74 & 0.76 & 0.24 & 0.26 & 0.00 & 0.00 \\
\hline Nitrogen & 0.44 & 0.59 & 0.41 & 0.56 & 0.00 & 0.00 & 0.72 & 0.78 & 0.22 & 0.28 & 0.00 & 0.00 \\
\hline Phosphorus & 0.85 & 0.90 & 0.10 & 0.14 & 0.00 & 0.00 & 0.92 & 0.93 & 0.07 & 0.08 & 0.00 & 0.00 \\
\hline Potassium & 0.57 & 0.67 & 0.31 & 0.41 & 0.01 & 0.02 & 0.67 & 0.69 & 0.28 & 0.30 & 0.02 & 0.02 \\
\hline Cadmium & 0.22 & 0.58 & 0.42 & 1.00 & 0.00 & 0.00 & 0.16 & 0.52 & 0.48 & 0.84 & 0.00 & 0.00 \\
\hline Chromium & 0.00 & 0.31 & 0.69 & 1.00 & 0.00 & 0.00 & 0.10 & 0.31 & 0.69 & 0.90 & 0.00 & 0.00 \\
\hline Copper & 0.13 & 0.26 & 0.74 & 0.87 & 0.00 & 0.00 & 0.00 & 0.00 & 1.00 & 1.00 & 0.00 & 0.00 \\
\hline Nickel & 0.38 & 0.54 & 0.46 & 0.62 & 0.00 & 0.00 & 0.23 & 0.36 & 0.64 & 0.77 & 0.00 & 0.00 \\
\hline Lead & 0.49 & 0.65 & 0.35 & 0.51 & 0.00 & 0.00 & 0.47 & 0.56 & 0.44 & 0.53 & 0.00 & 0.00 \\
\hline
\end{tabular}

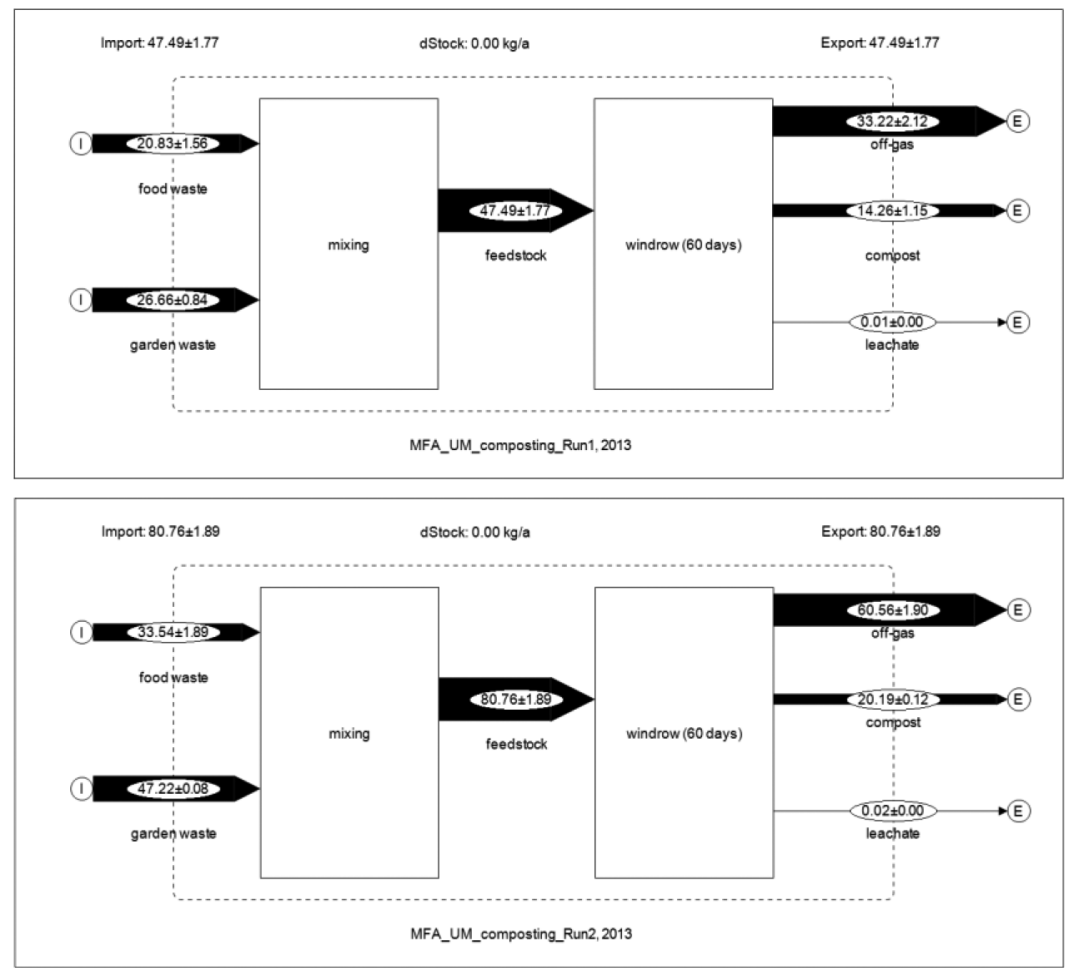

FIGURE 3. Substance (Carbon) flow in co-composting of food waste and yard waste 
agreement with the greater reduction of vs content in larger composting pile, which indicates higher rate of degradation process.

The total $\mathrm{N}$ loss during composting was $44-59 \%$ (Run 1) and $72-78 \%$ (Run 2). N loss in leachate was in all cases insignificant. It is important to note that $\mathrm{NH}_{3}$ was mostly emitted when the temperature was above $40-50^{\circ} \mathrm{C}$, the reason being two-fold. Firstly, above $40^{\circ} \mathrm{C}$, nitrification of ammonium to $\mathrm{NO}_{2}{ }_{2}^{-}$is inhibited and secondly the dissociation constant $(\mathrm{pKa})$ of $\mathrm{NH}_{4}^{+}$decreases with increasing temperature, meaning that higher temperatures favour evaporation of $\mathrm{NH}_{3}$. This could explain the greater emission of $\mathrm{N}$ in general in Run 2 (greater windrow size). The majority of the $\mathrm{N}$ lost during composting is assumed to be emitted as $\mathrm{N}_{2}$, which is an environmentally unproblematic compound.

\section{LEACHATE}

The volume of leachate collected in Run 1 and Run 2 sampling periods $(2.5-5 \mathrm{~L} /$ composting cycle) were in the range reported elsewhere in the literature. The leachate quantity ranged from 2.1 to $3.2 \mathrm{~L}$ per composting cycle (5 weeks) was recorded in an experiment with daily inputs of 2.1-3.0 kg household waste/person/day (Papadopoulos et al. 2009) whereas another experiment showed a leachate generation of 43-300 mL/day in two differently managed home composting units. The relatively high generation of leachate might reflect the high moisture content in food waste. The leachate generation is equivalent to 11.77-12.72 $\mathrm{L} / \mathrm{Mg}$ ww in the present study, is lower as compared to other similar study with daily inputs (Amlinger et al.2008). The composition of the leachate was within normal values for leachate from composting of organic waste.

\section{METHODOLOGICAL CHOICES}

There are three major activities in construction of an LCI namely: construction of the flow sheet; data collection and documentation and calculation of the environmental loads in terms of the functional unit. Of all these activities, data collection is the most time consuming and cost-intensive activity in a LCI construction. The data collection becomes more challenging when dealing with quantification of

TABLE 4. LCI data for windrow co-composting of food waste and yard waste in tropical environment

\begin{tabular}{|c|c|c|c|c|}
\hline & \multirow[t]{2}{*}{ LCI data } & \multicolumn{2}{|c|}{ amount } & \multirow[t]{2}{*}{ unit } \\
\hline & & $\min$ & $\max$ & \\
\hline \multirow[t]{2}{*}{ Input waste } & organic household waste yard waste & 112.4 & 193.0 & $\mathrm{~kg}$ \\
\hline & & 100.0 & 200.0 & $\mathrm{~kg}$ \\
\hline \multirow[t]{3}{*}{ Energy and materials consumption } & electricity & - & - & $\mathrm{L}$ \\
\hline & water (direct) & - & - & \\
\hline & water (cleaning) & 5.0 & 10.0 & \\
\hline \multirow[t]{14}{*}{ Gaseous emissions (to atmosphere) } & Carbon content & 0.1464 & 0.1664 & $\mathrm{~kg} / \mathrm{kg} \mathrm{ww}$ \\
\hline & CO2-C (biogenic) & 0.1391 & 0.1581 & $\mathrm{~kg} / \mathrm{kg} \mathrm{ww}$ \\
\hline & $\mathrm{CH} 4-\mathrm{C}$ & 0.0057 & 0.0065 & $\mathrm{~kg} / \mathrm{kg} \mathrm{ww}$ \\
\hline & $\mathrm{CO}-\mathrm{C}$ & 0.0015 & 0.0017 & $\mathrm{~kg} / \mathrm{kg} \mathrm{ww}$ \\
\hline & Nitrogen Content & 0.0052 & 0.0116 & $\mathrm{~kg} / \mathrm{kg} \mathrm{ww}$ \\
\hline & $\mathrm{N} 2 \mathrm{O}-\mathrm{N}$ & 0.0003 & 0.0007 & $\mathrm{~kg} / \mathrm{kg} \mathrm{ww}$ \\
\hline & NH3 & 0.0000 & 0.0000 & $\mathrm{~kg} / \mathrm{kg} \mathrm{ww}$ \\
\hline & $\mathrm{K}$ & 0.0027 & 0.0035 & $\mathrm{~kg} / \mathrm{kg} \mathrm{ww}$ \\
\hline & $\mathrm{P}$ & 0.5240 & 0.6692 & $\mathrm{~kg} / \mathrm{kg} \mathrm{ww}$ \\
\hline & $\mathrm{Cd}$ & 0.0186 & 0.1188 & $\mathrm{mg} / \mathrm{Gg} \mathrm{ww}$ \\
\hline & $\mathrm{Cr}$ & - & 0.6415 & $\mathrm{mg} / \mathrm{Gg} \mathrm{ww}$ \\
\hline & $\mathrm{Cu}$ & 0.8900 & 2.0252 & $\mathrm{mg} / \mathrm{Gg} \mathrm{ww}$ \\
\hline & $\mathrm{Ni}$ & 0.3259 & 1.3607 & $\mathrm{mg} / \mathrm{Gg} \mathrm{ww}$ \\
\hline & $\mathrm{Pb}$ & 2.2699 & 4.0483 & $\mathrm{mg} / \mathrm{Gg} \mathrm{ww}$ \\
\hline \multirow[t]{12}{*}{ Liquid emissions (to groundwater) } & Leachate & 0.0118 & 0.0127 & $\mathrm{~kg} / \mathrm{kg} \mathrm{ww}$ \\
\hline & $\mathrm{N}$ losses & 0.3766 & 1.0687 & $\mathrm{mg} / \mathrm{kg} \mathrm{ww}$ \\
\hline & C losses & 36.4977 & 43.0025 & $\mathrm{mg} / \mathrm{kg} \mathrm{ww}$ \\
\hline & BOD & 73.9360 & 103.4845 & $\mathrm{mg} / \mathrm{kg} \mathrm{ww}$ \\
\hline & COD & 159.9263 & 230.0414 & $\mathrm{mg} / \mathrm{kg} \mathrm{ww}$ \\
\hline & $\mathrm{K}$ & 55.7801 & 101.7812 & $\mathrm{mg} / \mathrm{kg} \mathrm{ww}$ \\
\hline & $\mathrm{P}$ & 641.2214 & 993.4087 & $\mathrm{mg} / \mathrm{kg} \mathrm{ww}$ \\
\hline & $\mathrm{Cd}$ & 17.8117 & 61.2053 & $\mathrm{mg} / \mathrm{Gg} \mathrm{ww}$ \\
\hline & $\mathrm{Cr}$ & 141.2429 & 235.4049 & $\mathrm{mg} / \mathrm{Gg} \mathrm{ww}$ \\
\hline & $\mathrm{Cu}$ & 211.8644 & 258.9454 & $\mathrm{mg} / \mathrm{Gg} \mathrm{ww}$ \\
\hline & $\mathrm{Ni}$ & 612.0527 & $1,058.5240$ & $\mathrm{mg} / \mathrm{Gg} \mathrm{ww}$ \\
\hline & $\mathrm{Pb}$ & 998.1168 & $1,804.0710$ & $\mathrm{mg} / \mathrm{Gg} \mathrm{ww}$ \\
\hline Finished product & Compost & 0.4021 & 0.2608 & $\mathrm{~kg} / \mathrm{kg} \mathrm{ww}$ \\
\hline
\end{tabular}


emissions to air and water, particularly from an open process such as composting. In particular, the modeling of direct emissions requires a large amount of parameters. (i.e. aerobic condition, moisture content, windrow size and climatic condition) An efficient solution in the frame of composting life cycle assessment is required. Some adaptions are necessary according to the goal and scope of the study.

To minimize the time consumption of direct measurement, an alternative methods such as SFA can be employed in the future. Based on the experience of SFA in the present study, the emissions quantified are likely to be in agreement with that from previous studies. SFA will be able to integrate a wide portfolio of LCI and eventually LCIA projects from the waste management sector.

\section{LIMITATIONS}

The discrepancy between the input and output values had caused the negative value, as shown in Figure 5. This might be related to the sampling technique. The input material was grab samples from very small quantities and small errors in the sampling could potentially lead to large uncertainties, especially in the heavy metal concentrations. They are most likely distributed more unevenly in the input waste. It is suggested that $\mathrm{C}$ and $\mathrm{N}$ compounds are more representative in grab method. Moreover, a very high variance in a range of parameters in the fraction of food waste was reported by Riber et al. (2007). It was concluded that the food waste could not be considered homogeneous despite the shredding process, and hence it is quite difficult to get a representative samples of such heterogeneous material. Therefore, this grad method for food waste sampling resulted in limitations to the assessment in term of large uncertainties. However, the uncertainties of the representative samples can be reduced by increasing the number of samples. The sampling of the output was done according to the quartering method and is thus believed to better represent the final output material. Despite the possibility of loss of emissions of heavy metal to the air as calculated by STAN 2.5 , it is however considered to be unproblematic, due to very low concentrations.

\section{FUTURE STUDIES}

The transfer coefficients of selected substances to air, compost and leachate of a co-composting process are shown in Table 3. The full LCI can stand as a platform for environmental assessments of co-composting systems for food waste and yard waste in tropical environment. The results of the present study provides information about all significant inputs and outputs in the form of elementary flow to and from the environment from all the unit processes involved. The information is essential for Life Cycle Assessment (LCA) for co-composting of food waste and yard waste in tropical countries. The Inventory analysis is followed by impact assessment to evaluate the significance of potential environmental impacts based on the LCI flow results from the present study.

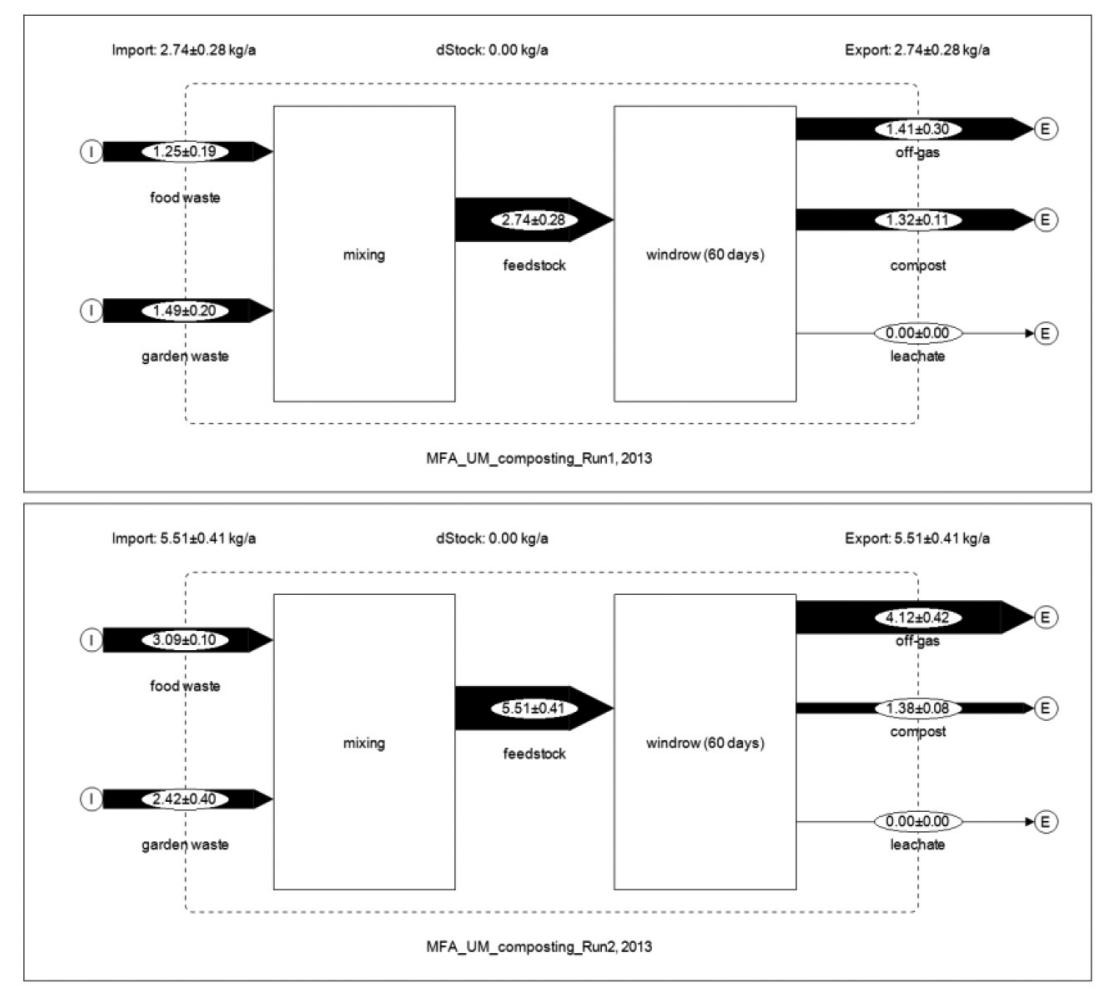

FIGURE 4. Substance (Nitrogen) flow in co-composting of food waste and yard waste 


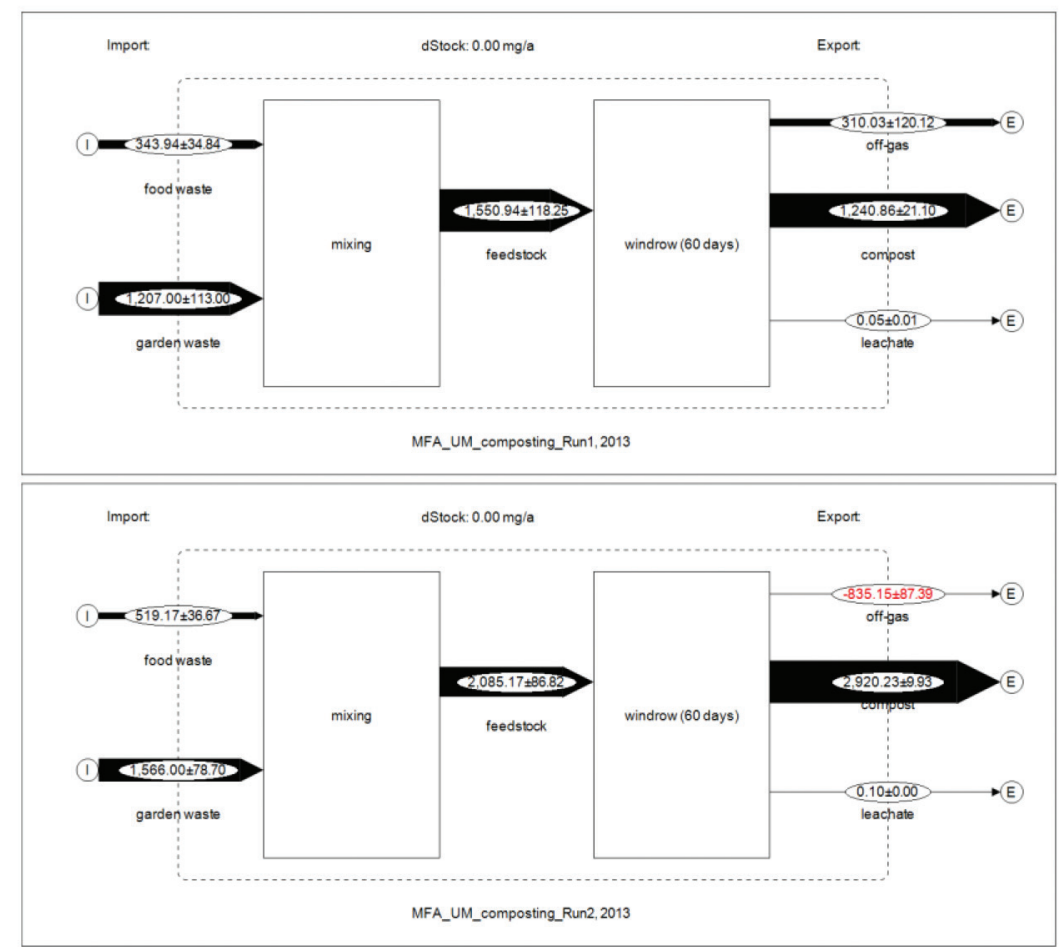

FIGURE 5. Substance (Copper) flow in co-composting of food waste and yard waste

\section{CONCLUSION}

A life cycle inventory was for the first time made for medium scaled co-composting of food waste and yard waste in tropical environment. An experimental set-up with two composting windrows for different size was performed for the duration of 60 days and contributions to environmental burdens were assessed. The composting windrows were fed with 212.4 and $393 \mathrm{~kg}$, respectively. The loss of $\mathrm{C}$ during composting was recorded in the range of $0.146-0.166 \mathrm{~kg} / \mathrm{kg}$ ww. The $\mathrm{C}$ losses via leachate were insignificant $(0.02 \%$ of the total input $\mathrm{C})$. The total $\mathrm{N}$ loss during the process was $0.005-0.012 \mathrm{~kg} / \mathrm{kg}$ ww. Due to unavailability of gas measuring equipment with suitable detection limits, the emission of $\mathrm{CO}_{2}, \mathrm{CH}_{4}, \mathrm{CO}$, $\mathrm{NH}_{3}$ and $\mathrm{N}_{2} \mathrm{O}$ were not measured. However, the emissions of these gas compounds were estimated via SFA. The leachate generation was measured as $0.012-0.013 \mathrm{~kg} / \mathrm{kg}$ ww. The flows of selected heavy metals were assessed. Heavy metals were of minor significance due to low concentrations in the inputs (food waste and yard waste). Heavy metals were found to be released to the atmosphere. However, majority of heavy metals remain in the finished compost. The $\mathrm{C} / \mathrm{N}$ reduction during the process was in the range of $10-23 \%$. In general, the compost composition was considered to be within the ranges previously reported in literature and thus ready for application as soil conditioner. The LCI presented in the present study can be used as a starting point for making environmental assessments of medium-scale co-composting of food waste and yard waste in tropical environment. No major environmental problems were identified from the process, except for the emissions of GHGs. The emissions of GHGs can be decreased by frequent mixing of the composting pile to avoid anaerobic condition within the pile.

\section{ACKNOWLEDGEMENTS}

The study was carried under PPP research grant PV0482011A with the cooperation from UM Cares for the contribution of facilities in carrying out composting experiment. The authors would like to express their gratitude to ISWA for conducting a SFA workshop on 'Application of SFA in waste management'.

\section{REFERENCES}

Adi, A. \& Noor, Z. 2009. Waste recycling: Utilization of coffee grounds and kitchen waste in vermicomposting. Bioresource Technology 100(2): 1027-1030.

Amlinger, F., Peyr, S. \& Cuhls, C. 2008. Green house gas emissions from composting and mechanical biological treatment. Waste Management Research 26(1): 47-60.

Andersen, J.K., Boldrin, A., Christensen, T.H. \& Scheutz, C. 2012. Home composting as an alternative treatment option for organic household waste in Denmark: An environmental assessment using life cycle assessment-modelling. Waste Management 32(1): 31-40.

Andersen, J.K., Boldrin, A., Christensen, T.H. \& Scheutz, C. 2011. Mass balances and life cycle inventory of home composting of organic waste. Waste Management 31(9): 1934-1942.

Cabaraban, M.T.I., Khire, M.V. \& Alocilja, E.C. 2008. Aerobic in-vessel composting versus bioreactor landfilling using life cycle inventory models. Clean Technologies and Environmental Policy 10(1): 39-52. 
Cencic, O. \& Rechberger, H. 2008. Material flow analysis with software STAN. Journal of Environmental Engineering and Management 18(1): 3-7.

Chen, T.C. \& Lin, C.F. 2008. Greenhouse gases emissions from waste management practices using life cycle inventory model. Journal of Hazardous Materials 155(1): 23-31.

Colón, J., Martínez-Blanco, J., Gabarrell, X., Artola, A., Sánchez, A., Rieradevall, J. \& Font, X. 2010. Environmental assessment of home composting. Resources, Conservation and Recycling 54(11): 893-904.

Fukumoto, Y., Osada, T., Hanajima, D. \& Haga, K. 2003. Patterns and quantities of $\mathrm{NH} 3, \mathrm{~N} 20$ and $\mathrm{CH} 4$ emissions during manure composting without forced aeration-effect of compost pile. Bioresource Technology 89(2): 109-114.

ISO. 1998. Environmental Management- Life Cycle AssessmentGoal and Scope Definition and Inventory Analysis (ISO:14041). Geneva: International Standards Organization.

Jasim, S. \& Smith, S.R. 2003. The practicability of home composting for the management of biodegradable domestic solid waste. London: Center for Environmental Control and Waste Management, Department of Civil and Environmental Engineering, Imperial College.

Khoo, H.H., Lim, T.Z. \& Tan, R.B.H. 2010. Food waste conversion options in Singapore: Environmental impacts based on an LCA perspective. Science of the Total Environment 408(6): 1367-1373.

Kim, M.H. \& Kim, J.W. 2010. Comparison through a LCA evaluation analysis of food waste disposal options from the perspective of global warming and resource recovery. Science of the Total Environment 408(19): 3998-4006.

Komilis, D.P. \& Ham, R.K. 2004. Life-cycle inventory of municipal solid waste and yard waste windrow composting in the United States. Journal of Environmental Engineering 130(11): 1390-1400.

Lee, S.H., Choi, K.I., Osako, M. \& Dong, J.I. 2007. Evaluation of environmental burdens caused by changes of food waste management systems in Seoul, Korea. Science of the Total Environment 387(1): 42-53.

Lundie, S. \& Peters, G.M. 2005. Life cycle assessment of food waste management options. Journal of Cleaner Production 13(3): 275-286.
Martínez-Blanco, J., Colón, J., Gabarrell, X., Font, X., Sánchez, A., Artola, A. \& Rieradevall, J. 2010. The use of life cycle assessment for the comparison of biowaste composting at home and full scale. Waste Management 30(6): 983-994.

Nair, J., Sekiozoic, V.\& Anda, M. 2006. Effect of pre-composting on vermicomposting of kitchen waste. Bioresource Technology 97(16): 2091-2095.

Papadopoulos, A.E., Stylianou, M.A., Michalopoulos, C.P., Moustakas, K.G., Hapeshis, K.M., Vogiatzidaki, E.E.I. \& Loizidou, M.D. 2009. Performance of a new household composter during in-home testing. Waste Management 29(1): 204-213.

PerkinElmer. 2012. Technologies for Mass Spectrometry. http:// www.perkinelmer.com/default.xhtml.

Rea, E., Pierandrei F., Rinaldi, S., De Lucia, B., Vecchietti, L. \& Ventrelli, A. 2009. Effect of Compost-Based Alternative Substrata in Potted Aloe Vera (L.) Burm. F. Acta Hort. (ISHS) 807. pp. 541-546

Riber, C., Rodushkin, I., Spliid, H. \& Christensen, T.H. 2007. Method for fractional soldi waste sampling and chemical analysis. International Journal of Environmental Analytical Chemistry 87(5): 321-335.

Russo, G., De Lucia, B., Vecchietti, L., Rea, E. \& Leone, A. 2011. Environmental and agronomical analysis of different compost-based peat-free substrates in potted Rosemary. Acta Hort.(ISHS). 891.pp. 265-272.

Zhao, W., van der Voet, E., Zhang, Y. \& Huppes, G. 2009. Life cycle assessment of municipal solid waste management with regard to greenhouse gas emissions: case study of Tianjin, China. Science of the Total Environment 407: 1517-1526.

Department of Civil Engineering

University of Malaya

50603 Kuala Lumpur

Malaysia

*Corresponding author; email: guancher@ hotmail.com

Received: 19 September 2013

Accepted: 19 October 2014 